\title{
MULTIDIMENSIONAL ANALYSIS \\ OF THE GREEN GROWTH OF THE EUROPEAN UNION COUNTRIES IN 2019
}

\author{
Angelika Kantor \\ Department of Consumer Research, University of Economics in Katowice, Katowice, Poland \\ e-mail: angelika.kantor@edu.uekat.pl
}

ORCID: 0000-0002-3775-731X

(C) 2021 Angelika Kantor

This work is licensed under the Creative Commons Attribution-ShareAlike 4.0 International License. To view a copy of this license, visit http://creativecommons.org/licenses/by-sa/4.0/

Quote as: Kantor, A. (2021). Multidimensional analysis of the green growth of the European Union countries in 2019. Econometrics. Ekonometria. Advances in Applied Data Analysis, 25(2).

DOI: 10.15611/eada.2021.2.04

JEL Classification: C38, F64, O44, Q01, Q50, Q56, Q58

\begin{abstract}
Green growth is a new approach to the economy that assumes the efficient use of raw materials while minimizing the negative impact on the environment. The aim of the study is to assess green growth in the European Union countries in 2019. For this purpose, secondary data was used and a multidimensional analysis of sustainable development was performed. The non-pattern model together with the Hellwig and Ward methods were implemented. This enabled a comparison between countries, and their classification due to a similar level of development. Based on the analysis, a large discrepancy in terms of green growth was observed in the examined countries. It was noted that the disproportion may turn out to be a problem in the implementation of the sustainable development policy. The results also showed that the position of the country is reflected in its geographic location.
\end{abstract}

Keywords: green growth, Hellwig method, multivariate analyses, sustainable development taxonomic methods.

\section{Introduction}

Global changes attract the interest of researchers and decision-makers in many countries, as well as of general public. Growing environmental awareness and the shift towards sustainable development are conducive when focusing on green growth. Therefore, changes in the economy are possible (Kirchherr, Reike, and Hekkert, 2017). Changes can also be seen in the initiatives taken by companies. Enterprises take initiatives in the field of corporate social responsibility (CSR) and this allows them to stay ahead of regulations and gain favour with consumers. 
Changes in green growth should be based on comprehensive indicators that will make it possible to compare progress across countries (Kim, Kim, and Chae, 2014). Thanks to which they can be used at national (development of policy, objectives, priorities) and international level. Currently there are studies on green economy, but quantitative research on green growth is still lacking. The aim of the study is to assess green growth in the European Union countries in 2019. To be able to achieve the goal of the study, secondary data were used and a multidimensional analysis performed. The following research questions were posed:

- What is the level of green growth in the European Union countries?

- Is there a similarity in the realization of green growth?

The period under study was limited to one year. Due to the lack of completeness of data, not all EU countries were included for the analysis.

The article consists of five parts. The second section is devoted to a literature review, while the third describes the methods and formulas used. The research results are presented in Section 4. The last section contains conclusions and recommendations for future research.

\section{Literature review}

One of the most popular issues in the 21st century is the concept of sustainable development. This is a popular research topic and a ubiquitous development paradigm (Ukaga, Maser, and Reichenbach, 2011). According to the United Nations (UN) definition, sustainable development is a "development that meets the needs of the present without compromising the ability of future generations to meet their own needs" (United Nations General Assembly, 1987).

Sustainable development can be understood as maintaining a balance between the key components of development (Ministerstwo Środowiska, 1999). The concept assumes the simultaneous protection of the natural environment, social justice and the achievement of economic development (Zarębska, 2017). The concept of sustainable development assumes benefits in three areas: nature, society and economy (Rokicka and Woźniak, 2016). This is the overall objective of the European Union, which is reflected, among others, in the Europe 2020 Strategy (2010), the Strategy for sustainable development (2001), the Lisbon Strategy (2000) and the Amsterdam Treaty (1997).

According to Stoddart et al. (2011), sustainable development should lead to a fair distribution of resources between generations. Ben-Eli (2015) stresses the relationship between the carrying capacities and the population. Human activities should use human potential but should not allow for irreversible changes. Therefore, human activity should be based on meeting needs without depleting natural resources (Thomas, 2015). The concept of sustainable development combines various levels, focusing on human responsibility for the environment. 
Sustainable development should be considered on moral, economic, legal, political, ecological and technical levels (Pawłowski, 2006). Considering the concept of sustainable development, one can notice a common element shaping the quality of life of future generations and the participation of non-material aspects of the quality of life (Florczak, 2008). It has been noted that innovation is a driving force for sustainable development (Silvestrea and Țîrcă, 2019). The concept was the starting point for green growth (Wyszkowska and Rogalska, 2014). In 2008, the possibility of a new model of the economy and recovery from the economic crisis was noticed. Through the Global Green New Deal, countries are to meet the challenge according to their climate and environment. The plan is to be based on a just transformation in all social areas, with social inclusion.

With the growing public awareness and the implementation of sustainable development goals, new directions of economic development have emerged. In addition to the circular economy, one should mention the so-called 'green growth' (Kasztelan, 2015). The green growth of countries means promoting economic development with the rational use of natural resources which, through natural capital, will ensure human well-being (OECD, 2011). The World Bank defines it as effective growth that minimizes negative environmental impact (2012), and because of this it is possible to create more value in limiting resource use (European Commission, 2016). Thus green growth is based on environmentally friendly decisions. According to UNEP (2011), it contributes to the improvement of welfare while reducing environmental risks. It has been noted that green growth is the power of future development (Ryszkowska, 2013). This is reflected in the EU's Europe 2020 strategy. The concept of green growth can be understood as long-term investments that are related to reducing the negative impact on the environment and increasing income at the same time (Dauvergne, 2021). Nevertheless, while performing such actions, one should take into account technological changes and the depletion of natural resources. Green growth is based on processes that are resource efficient. It can be seen that through green growth, benefits can be achieved at many economic and social levels (Acemoglu, Aghion, Bursztyn, and Hemous, 2011), and it is a response to an ecological breakdown (Hickel and Kallis, 2020).

In the framework, green growth should stimulate green investment and use natural resources efficiently. Such action will allow to maintain economic progress in the long term and improve the quality of life of the population. Green growth is a response to the oncoming environmental crisis and the popular interest in sustainable development.

It was found that a pro-environmental approach can be the engine of economic growth (Jacobs, 2012), while green growth is supposed to be a cleaner approach to the economy without slowing it down (Hallegatte, Heal, Fay, and Treguer, 2012). By protecting the environment, countries gain natural capital that contributes to the productive function which in turn, leads to an increase in income. The living environment is improving as people breathe cleaner air, drink clean water and eat 
healthier food. As a result, expenditure on health care is reduced and the satisfaction of the population is improved. To talk about sustainable development, one should consider the social, economic and environmental pillars (Perło and Roszkowska, 2011). Therefore, measuring GDP is an imperfect measure of growth as it does not take into account, among others, the living conditions of the population and environmental issues. Green growth should create optimal conditions for the market to avoid unfavorable activities for the economy and the environment. For green growth to become possible, not only concepts and regulations are necessary, but also regular measurement. Thanks to this, it will be possible to track changes taking place in the economy, as well as to identify the greenest countries.

Green growth is enjoying growing interest (Stoknes and Rockstrom, 2018), as reflected in the initiatives of OECD, UNEP and the World Bank. OECD has prepared the Green Growth Indicators 2017 report, in which the actions of countries are assessed on the basis of the presented indicators. In turn, the World Bank contributes to the popularization of the economics of green growth (e.g. Economics of Green Growth Peer-Assisted Learning). The implementation of practices favouring green growth by companies can be felt by their employees. Green investments have a positive effect on the condition of the natural environment and can be noticed in the workplace (Sulich, Grudziński, and Kulhanek, 2020).

Nowadays, green growth is the basis for the development of development strategies for OECD countries and their regulations (Wang, Sun, and Guo, 2019). Green growth is also reported on in scientific publications (Khoshnava et al., 2020). It should be emphasized that for a green growth policy to be effective, increased awareness of decision makers is necessary (Alrasheedi et al., 2020).

\section{Methodology}

A multivariate analysis of the level of green growth of the EU countries in 2019 was performed on the basis of secondary data. The data was taken from the OECD.stat website and then calculations were made using SPSS and Excel software.

The multidimensional analysis of the level of sustainable development in the European Union countries in 2019 was made on the basis of indicators used to monitor progress towards green growth. The indicators are divided into five groups (OECD, 2017):

- environmental and resource productivity,

- natural asset base,

- environmental dimension of quality of life,

- economic opportunities and policy responses,

- socio-economic context.

The groups were divided into individual thematic areas using the methods of taxonomic analysis. The indicators were proposed in the Green Growth Indicators 2017 study, and were the starting point for considering the assessment of green 
growth in the EU countries. Taking into account the substantive, formal and statistical criteria, a selection of variables was made (Strahl, 2006).

Based on the obtained data, the variables were selected. Due to the lack of data, some countries were omitted from the analysis, namely Bulgaria, Croatia, Cyprus, Malta and Romania. Considering the completeness of the data and the substantive premises, 23 variables were selected. Then, the coefficient of variation was calculated and those variables with the coefficient of variation greater than $10 \%$ were selected for further analysis. It was assumed that variables with a coefficient of variation above $10 \%$ can be considered diagnostic. The number of variables included in the analysis was 18 .

In order to examine the level of sustainable development, the Hellwig method was used, a Hellwig synthetic development measure was constructed and a non-pattern was employed. Groups of countries with high, medium and low development were distinguished. To complete the analysis, the spatial classification of countries was made using Ward's method, which made it possible to classify them according to a similar level of development. The results are presented in the form of dendrograms. Using the radar chart, the positions of the countries under the Hellwig method and non-pattern are shown.

Table 1. Diagnostic variables

\begin{tabular}{|c|c|c|}
\hline Area & Name & Variable \\
\hline \multirow[t]{6}{*}{$\begin{array}{l}\text { Environmental and } \\
\text { resource productivity }\end{array}$} & $\mathrm{x}_{1}$ & $\begin{array}{l}\text { Production-based } \mathrm{CO}_{2} \text { productivity, GDP per unit of energy- } \\
\text {-related } \mathrm{CO}_{2} \text { emissions }\end{array}$ \\
\hline & $\mathrm{x}_{2}$ & Production-based $\mathrm{CO}_{2}$ emissions \\
\hline & $\mathrm{x}_{3}$ & $\mathrm{CO}_{2}$ emissions from air transport per capita \\
\hline & $\mathrm{x}_{4}$ & Energy productivity, GDP per unit of TPES \\
\hline & $\mathrm{x}_{5}$ & Renewable energy supply, \% total energy supply \\
\hline & $\mathrm{x}_{6}$ & Non-energy material productivity, GDP per unit of DMC \\
\hline Natural asset base & $\mathrm{x}_{7}$ & Annual surface temperature, change since 19511980 \\
\hline \multirow{6}{*}{$\begin{array}{l}\text { Environmental } \\
\text { dimension of quality } \\
\text { of life }\end{array}$} & $\mathrm{x}_{8}$ & Mean population exposure to PM2.5 \\
\hline & $\mathrm{x}_{9}$ & $\begin{array}{l}\text { Percentage of population exposed to more than } 10 \text { micro- } \\
\text { grams } / \mathrm{m}^{3}\end{array}$ \\
\hline & $\mathrm{x}_{10}$ & Mortality from exposure to ambient PM2.5 \\
\hline & $\mathrm{x}_{11}$ & Mortality from exposure to ambient ozone \\
\hline & $\mathrm{x}_{12}$ & Mortality from exposure to lead \\
\hline & $\mathrm{x}_{13}$ & Mortality from exposure to residential radon \\
\hline \multirow{2}{*}{$\begin{array}{l}\text { Economic opportunities } \\
\text { and policy responses }\end{array}$} & $\mathrm{x}_{14}$ & Environmentally related taxes, \% GDP \\
\hline & $\mathrm{x}_{15}$ & Terrestrial protected area, $\%$ land area \\
\hline \multirow[t]{3}{*}{ Socio-economic context } & $\mathrm{x}_{16}$ & Real GDP, Index $2000=100$ \\
\hline & $\mathrm{x}_{17}$ & Total fertility rate, children per woman \\
\hline & $\mathrm{x}_{18}$ & Population density, inhabitants per $\mathrm{km}^{2}$ \\
\hline
\end{tabular}

Source: own elaboration based on data OECD.stat. 
As many as 18 indicators were selected for the analysis of green growth which formed the basis of the ratio analysis, the construction of the synthetic measure of sustainable development, and the classification. The selected diagnostic variables are presented in Table 1.

Among the selected indicators, the variables $\mathrm{X}_{2}, \mathrm{X}_{3}, \mathrm{X}_{7}-\mathrm{X}_{13}, \mathrm{X}_{18}$ are destimulants. This means that a lower value has a positive effect on the analyzed phenomenon. The diagnostic variables represent all areas of green growth that were highlighted in the Green Growth Indicators 2017 report.

\subsection{The Hellwig synthetic development measure}

This study uses the Hellwig method and the Hellwig synthetic indicator. The calculations were made as follows (Hellwig, Siedlecka, and Siedlecki, 1997):

1. Change of variables into stimulants and destimulants and change of destimulants into stimulants

2. Standardization of features to ensure comparability

$$
z_{i k}=\frac{x_{i k}-\bar{x}_{k}}{S_{k}}
$$

for: $x \in 1 ; i=1, \ldots, n ; k=1, \ldots, m$,

where: 1 - collection of stimulants; $\mathrm{Z}_{i k}$ - standardized value of feature $k$ for country $i$; $\mathrm{X}_{i k}$ - value of the $k$ feature in country $i ; \bar{x}_{k}$ - the mean of the sample; $S_{k}-$ the standard deviation of the sample; $m$ - number of variables; $n$ - number of countries.

3. Designating a pattern with the highest values for stimulants

$$
P_{0}=\left[z_{01}, \mathrm{z}_{02}, \ldots \mathrm{z}_{0 k}\right]
$$

where: $Z_{0 k}=\max \left\{z_{i k}\right\}-$ when $x_{k}$ is stimulant.

4. Calculation of the Euclidean distance

$$
C_{i 0}=\sqrt{\sum_{k=1}^{m}\left(Z_{i k}-Z_{0 k}\right)^{2}}
$$

$i=1,2,3, \ldots n$.

5. Constructing a taxonomically relative measure of development that takes values from $0-1$. The closer the value is to 1 , the closer the object is to the pattern, and therefore shows a higher level of green growth

$$
d_{i}=1-\frac{c_{i 0}}{c_{0}}
$$

$i=1,2,3, \ldots n$. 
where:

$$
c_{0}=\bar{c}_{0}+2 \cdot s_{0}
$$

$\bar{c}_{0}, s_{0}$ - arithmetic mean and standard deviation of the sequence $(i=1,2,3, \ldots n)$; $d_{i}$ - synthetic indicator

wherein:

$$
\bar{c}_{0}=\frac{1}{n} \cdot \sum_{i=1}^{n} c_{i o}
$$

and

$$
s_{0}=\sqrt{\frac{1}{n} \cdot \sum_{i=1}^{n}\left(c_{i 0}-\bar{c}_{0}\right)^{2}} .
$$

6. Classification of countries according to identified development. There are three groups according to the level of development: high, medium, low:

I. high: $d_{i}>\bar{d}_{i}+S_{d_{i}}$,

II. medium: $\bar{d}_{i}-S_{d_{i}}<\mathrm{d}_{\mathrm{i}}<\bar{d}_{i}+S_{d_{i}}$,

III. low: $d_{i}<\bar{d}_{i}-S_{d_{i}}$,

where: $d_{i}$ - value of the synthetic indicator; $\bar{d}_{i}-$ arithmetic mean of the synthetic indicator; $S_{d_{i}}$-standard deviation of the synthetic indicator.

\subsection{Non-pattern measure of development}

The study uses the non-pattern measure of development (Młodak, 2006), which is the arithmetic mean of normalized characteristics. The method is described by the formula:

$$
h_{i}=\frac{1}{p} \sum_{j=1}^{p} x_{i j}
$$

$i=1, \ldots, n$.

Then the classification was made into three intervals:

I. high: $h_{i}>\bar{h}_{i}+S_{h_{i}}$,

II. medium: $\frac{i}{h_{i}}-S_{h_{i}}<h_{i}<\bar{h}_{i}+S_{h_{i}}$,

III. low: $h_{i}<\bar{h}_{i}-S_{h_{i}}$,

where: $h_{i}$ - value of a non-pattern synthetic measure; $\bar{h}_{i}-$ arithmetic average non-pattern synthetic measure; $S_{h_{i}}$ - standard deviation non-pattern synthetic measure. 


\subsection{Ward's method}

In order to classify countries into cluster, Ward's hierarchic method was performed. The measure of the diversity of the cluster in relation to the mean values is ESS (Error Sum of Squares), which is defined by the following formula (e.g. Kubiczek and Hadasik, 2021; Walesiak, 2009; Ward, 1963):

$$
E E S=\sum_{i=1}^{k}\left(x_{i}-\bar{x}\right)^{2}
$$

where: $x_{i}$ - value of the variable which is the segmentation criterion for the $i$-th object; $k$-number of objects in a cluster.

The assumption of this method is to minimize the sum of the squared deviations of any two clusters that may be formed at any step of analysis. Ward's method is perceived as effective due to the creation clusters even of a small size. Nonetheless, Ward's method is generally regarded as the most effective agglomeration methods (Basiura and Sokołowski, 2005).

In this study, Ward's method was used to classify countries due to a similar level of development. The results are presented in the form of a dendrogram created in the SPSS program. Furthermore, the map shows the spatial variation of the results.

\section{Results}

Table 2 presents the calculated taxonomic values of the green growth measure by three groups. The synthetic Hellwig indicator was ordered linearly according to decreasing values. On its basis, three groups of countries were distinguished, differing in the level of development. The first group that reports a high level of sustainable development includes three countries: the United Kingdom, Denmark, Ireland; 16 of the surveyed countries have an average level of development: Sweden, France, Luxembourg, Lithuania, Latvia, Austria, Estonia, Spain, Finland, Slovenia, Portugal, the Netherlands, Germany, the Slovak Republic, Italy, Belgium. There are four countries in the low level of development group: the Czech Republic, Poland, Greece, Hungary.

Table 2. Taxonomic values of Hellwig's development by groups

\begin{tabular}{|c|c|}
\hline Country & $d_{i}$ \\
\hline 1 & 2 \\
\hline \multicolumn{2}{|c|}{$\begin{array}{l}\text { Group I - high level of development } \\
\qquad d_{i} \geq 0.288\end{array}$} \\
\hline United Kingdom & 0.346 \\
\hline Denmark & 0.335 \\
\hline Ireland & 0.323 \\
\hline
\end{tabular}


Table 2, cont.

\begin{tabular}{|c|c|}
\hline 1 & 2 \\
\hline \multicolumn{2}{|c|}{$\begin{array}{c}\text { Group II - medium level of development } \\
0.096 \leq \mathrm{d}_{\mathrm{i}} \leq 0.288\end{array}$} \\
\hline Sweden & 0.286 \\
\hline France & 0.272 \\
\hline Luxembourg & 0.263 \\
\hline Lithuania & 0.258 \\
\hline Latvia & 0.253 \\
\hline Austria & 0.239 \\
\hline Estonia & 0.218 \\
\hline Spain & 0.206 \\
\hline Finland & 0.201 \\
\hline Slovenia & 0.191 \\
\hline Portugal & 0.188 \\
\hline Netherlands & 0.173 \\
\hline Germany & 0.140 \\
\hline Slovak Republic & 0.138 \\
\hline Italy & 0.129 \\
\hline Belgium & 0.121 \\
\hline \multicolumn{2}{|c|}{$\begin{array}{c}\text { Group III - low level of development } \\
\qquad \mathrm{d}_{\mathrm{i}}<0.096\end{array}$} \\
\hline Czech Republic & 0.054 \\
\hline Poland & 0.035 \\
\hline Greece & 0.023 \\
\hline Hungary & 0.015 \\
\hline
\end{tabular}

Source: own elaboration.

The development of green growth is presented in Figure 1.

Based on the data, a large variation in development within green growth can be seen. Although the United Kingdom shows the greatest green growth, it is not a leader in any area, while Denmark is the best when it comes to environmental performance and resources. Sweden has the highest rate of green growth in the environment area and ranks first in the environmental dimension of quality of life, while Ireland ranks first in the natural asset base area. The area of economic opportunities and policy responses is headed by Slovenia. In the area of the socio-economic context, Ireland stands out with the highest level of the indicator. The taxonomic values of the development measure broken down by areas are presented in Table 3. 
0.4

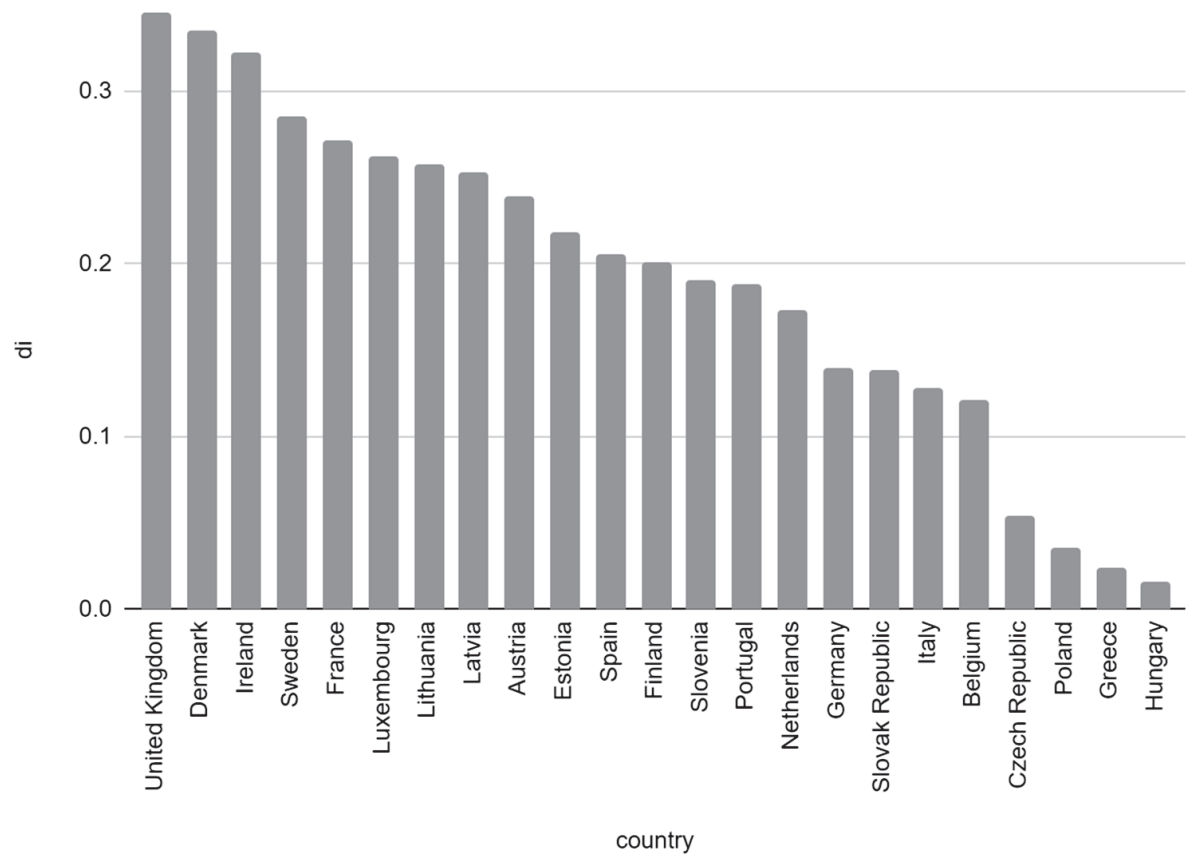

Fig. 1. Green growth indicator in the selected EU countries

Source: own elaboration based on data OECD.stat.

Table 3. Taxonomic values of Hellwig's development divided into areas

\begin{tabular}{|c|c|c|c|c|c|c|c|c|c|}
\hline \multicolumn{2}{|c|}{$\begin{array}{l}\text { Environmental } \\
\text { and resource } \\
\text { productivity }\end{array}$} & \multicolumn{2}{|c|}{ Natural asset base } & \multicolumn{2}{|c|}{$\begin{array}{l}\text { Environmental } \\
\text { dimension } \\
\text { of quality of life }\end{array}$} & \multicolumn{2}{|c|}{$\begin{array}{c}\text { Economic } \\
\text { opportunities and } \\
\text { policy responses }\end{array}$} & \multicolumn{2}{|c|}{$\begin{array}{l}\text { Socio-economic } \\
\text { context }\end{array}$} \\
\hline Country & $\mathrm{d}_{\mathrm{i}}$ & Country & $d_{\text {i }}$ & Country & $d_{i}$ & Country & $\mathrm{d}_{\mathrm{i}}$ & Country & $d_{\text {i }}$ \\
\hline 1 & 2 & 3 & 4 & 5 & 6 & 7 & 8 & 9 & 10 \\
\hline \multicolumn{2}{|c|}{$\begin{array}{c}\text { Group I - high level } \\
\text { of development } \\
d_{i} \geq 0.304\end{array}$} & \multicolumn{2}{|c|}{$\begin{array}{c}\text { Group I - high level } \\
\text { of development } \\
d_{i} \geq 0.802\end{array}$} & \multicolumn{2}{|c|}{$\begin{array}{c}\text { Group I - high level } \\
\text { of development } \\
d_{i} \geq 0.677\end{array}$} & \multicolumn{2}{|c|}{$\begin{array}{c}\text { Group I - high level } \\
\text { of development } \\
d_{i} \geq 0.569\end{array}$} & \multicolumn{2}{|c|}{$\begin{array}{c}\text { Group I - high level } \\
\text { of development } \\
d_{i} \geq 0.660\end{array}$} \\
\hline Denmark & 0.433 & Ireland & 1.00 & Sweden & 0.849 & Slovenia & 0.973 & Ireland & 0.913 \\
\hline $\begin{array}{l}\text { United King- } \\
\text { dom }\end{array}$ & 0.324 & \begin{tabular}{|l} 
United \\
Kingdom
\end{tabular} & 0.968 & Finland & 0.774 & Poland & 0.605 & Lithuania & 0.793 \\
\hline Italy & 0.318 & Portugal & 0.931 & Ireland & 0.769 & - & - & Latvia & 0.763 \\
\hline Sweden & 0.314 & Spain & 0.887 & Estonia & 0.731 & - & - & Estonia & 0.685 \\
\hline- & - & Finland & 0.848 & - & - & - & - & - & - \\
\hline- & - & Greece & 0.834 & - & - & - & - & - & - \\
\hline
\end{tabular}


Table 3, cont.

\begin{tabular}{|c|c|c|c|c|c|c|c|c|c|}
\hline 1 & 2 & 3 & 4 & 5 & 6 & 7 & 8 & 9 & 10 \\
\hline \multicolumn{2}{|c|}{$\begin{array}{c}\text { Group II - medium } \\
\text { level of development } \\
0.102 \leq \mathrm{d}_{\mathrm{i}} \leq 0.305\end{array}$} & \multicolumn{2}{|c|}{$\begin{array}{c}\text { Group II - medium } \\
\text { level of development } \\
0.267 \leq \mathrm{d}_{\mathrm{i}} \leq 0.802\end{array}$} & \multicolumn{2}{|c|}{$\begin{array}{c}\text { Group II - medium } \\
\text { level of development } \\
0.226 \leq \mathrm{d}_{\mathrm{i}} \leq 0.677\end{array}$} & \multicolumn{2}{|c|}{$\begin{array}{c}\text { Group II }- \text { medium } \\
\text { level } \\
\text { of development } \\
0.190 \leq \mathrm{d}_{\mathrm{i}} \leq 0.569\end{array}$} & \multicolumn{2}{|c|}{$\begin{array}{c}\text { Group II - medium } \\
\text { level of development } \\
0.220 \leq \mathrm{d}_{\mathrm{i}} \leq 0.660\end{array}$} \\
\hline Austria & 0.283 & Sweden & 0.790 & $\begin{array}{l}\text { United } \\
\text { Kingdom }\end{array}$ & 0.668 & $\begin{array}{l}\text { Luxem- } \\
\text { bourg }\end{array}$ & 0.520 & $\begin{array}{l}\text { Slovak } \\
\text { Republic }\end{array}$ & 0.601 \\
\hline Spain & 0.281 & Italy & 0.727 & Lithuania & 0.629 & $\begin{array}{l}\text { Slovak } \\
\text { Republic }\end{array}$ & 0.499 & Sweden & 0.585 \\
\hline Portugal & 0.263 & France & 0.553 & Luxembourg & 0.575 & Germany & 0.445 & $\begin{array}{l}\text { Czech } \\
\text { Republic }\end{array}$ & 0.582 \\
\hline Latvia & 0.253 & Belgium & 0.501 & France & 0.574 & Austria & 0.443 & Slovenia & 0.523 \\
\hline Ireland & 0.248 & Netherlands & 0.463 & Denmark & 0.556 & $\begin{array}{l}\text { Nether- } \\
\text { lands }\end{array}$ & 0.419 & Poland & 0.513 \\
\hline Luxemburg & 0.228 & Denmark & 0.451 & Netherlands & 0.534 & $\begin{array}{l}\text { United } \\
\text { Kingdom }\end{array}$ & 0.415 & Hungary & 0.474 \\
\hline France & 0.225 & Luxembourg & 0.443 & Germany & 0.487 & Italy & 0.407 & France & 0.454 \\
\hline Lithuania & 0.223 & Estonia & 0.422 & Austria & 0.438 & \begin{tabular}{|l} 
France \\
\end{tabular} & 0.401 & Denmark & 0.439 \\
\hline Netherlands & 0.222 & Germany & 0.355 & Latvia & 0.431 & Greece & 0.382 & Austria & 0.395 \\
\hline Greece & 0.198 & Austria & 0.336 & Portugal & 0.397 & Portugal & 0.375 & \begin{tabular}{|l|} 
United \\
Kingdom
\end{tabular} & 0.372 \\
\hline Belgium & 0.156 & Slovenia & 0.330 & Spain & 0.368 & Estonia & 0.365 & Finland & 0.363 \\
\hline Slovenia & 0.152 & Hungary & 0.312 & Belgium & 0.340 & Belgium & 0.358 & Luxembourg & 0.351 \\
\hline $\begin{array}{l}\text { Slovak } \\
\text { Republic }\end{array}$ & 0.129 & Latvia & 0.289 & Slovenia & 0.318 & $\begin{array}{l}\text { Czech } \\
\text { Republic }\end{array}$ & 0.355 & Germany & 0.319 \\
\hline Hungary & 0.120 & $\begin{array}{l}\text { Slovak } \\
\text { Republic }\end{array}$ & 0.283 & $\begin{array}{l}\text { Slovak } \\
\text { Republic }\end{array}$ & 0.267 & Latvia & 0.353 & Spain & 0.282 \\
\hline- & - & - & - & - & - & Hungary & 0.343 & Belgium & 0.250 \\
\hline- & - & - & - & - & - & Spain & 0,342 & - & - \\
\hline- & - & - & - & - & - & Denmark & 0.292 & - & - \\
\hline- & - & - & - & - & - & Finland & 0.241 & - & - \\
\hline- & - & - & - & - & - & Lithuania & 0.211 & - & - \\
\hline \multicolumn{2}{|c|}{$\begin{array}{c}\text { Group III - low level } \\
\text { of development } \\
d_{i}<0.102\end{array}$} & \multicolumn{2}{|c|}{$\begin{array}{c}\text { Group III - low level } \\
\text { of development } \\
\mathrm{d}_{\mathrm{i}}<0.267\end{array}$} & \multicolumn{2}{|c|}{$\begin{array}{c}\text { Group III - low level } \\
\text { of development } \\
\mathrm{d}_{\mathrm{i}}<0.226\end{array}$} & \multicolumn{2}{|c|}{$\begin{array}{c}\text { Group III - } \\
\text { low level of } \\
\text { development } \\
\mathrm{d}_{\mathrm{i}}<0.190 \\
\end{array}$} & \multicolumn{2}{|c|}{$\begin{array}{c}\text { Group III - low level } \\
\text { of development } \\
\mathrm{d}_{\mathrm{i}}<0.220\end{array}$} \\
\hline Finland & 0.082 & $\begin{array}{l}\text { Czech } \\
\text { Republic }\end{array}$ & 0.229 & Italy & 0.215 & Ireland & 0.081 & Portugal & 0.173 \\
\hline Germany & 0.077 & Lithuania & 0.187 & $\begin{array}{l}\text { Czech } \\
\text { Republic }\end{array}$ & 0.187 & Sweden & 0,999 & Greece & 0.113 \\
\hline $\begin{array}{l}\text { Czech } \\
\text { Republic }\end{array}$ & 0.067 & Poland & 0.167 & Poland & 0.151 & - & - & Italy & 0.103 \\
\hline Estonia & 0.043 & - & - & Greece & 0.067 & - & - & Netherlands & 0.076 \\
\hline Poland & 0.030 & - & - & Hungary & 0.048 & - & - & - & - \\
\hline
\end{tabular}

Source: own elaboration.

Calculations were also made on the non-pattern grouping measure. The results are presented in Table 4. 
Table 4. Taxonomic values of the development of a non-pattern measure by groups

\begin{tabular}{|c|c|}
\hline Country & $\mathrm{h}_{\mathrm{i}}$ \\
\hline \multicolumn{2}{|c|}{$\begin{array}{c}\text { Group I - high level of development } \\
\qquad h_{i} \geq 0.621\end{array}$} \\
\hline Sweden & 0.706 \\
\hline Ireland & 0.697 \\
\hline Estonia & 0.638 \\
\hline Finland & 0.635 \\
\hline \multicolumn{2}{|c|}{$\begin{array}{c}\text { Group II - medium level of development } \\
0.422 \leq \mathrm{h}_{\mathrm{i}} \leq 0.621\end{array}$} \\
\hline Denmark & 0.616 \\
\hline United Kingdom & 0.606 \\
\hline Latvia & 0.583 \\
\hline Lithuania & 0.577 \\
\hline France & 0.549 \\
\hline Luxembourg & 0.546 \\
\hline Portugal & 0.533 \\
\hline Slovenia & 0.517 \\
\hline Netherlands & 0.516 \\
\hline Austria & 0.510 \\
\hline Spain & 0.501 \\
\hline Slovak Republic & 0.456 \\
\hline Belgium & 0.443 \\
\hline Germany & 0438 \\
\hline Italy & 0.422 \\
\hline \multicolumn{2}{|c|}{$\begin{array}{c}\text { Group III - low level of development } \\
\qquad h_{i}<0.422\end{array}$} \\
\hline Czech Republic & 0.395 \\
\hline Poland & 0.382 \\
\hline Greece & 0.376 \\
\hline Hungary & 0.350 \\
\hline
\end{tabular}

Source: own elaboration.

Sweden is the country with the highest overall index calculated using a standardized measure. It also ranks first in the area of environmental and resource productivity and in high-development groups in the areas of the environmental dimension of quality of life and the socio-economic context. Ireland stands out for its high level of development in the areas of the natural asset base, the environmental dimension of quality of life and the socio-economic context. Estonia is in the high development group when it comes to environmental quality of life and socio-economic context, while Finland is in the environmental dimension of quality of life and the natural asset base. The taxonomic values of the measure by area are presented in Table 5. 
Table 5. Taxonomic values of the non-pattern measure with the division into areas

\begin{tabular}{|c|c|c|c|c|c|c|c|c|c|}
\hline \multicolumn{2}{|c|}{$\begin{array}{l}\text { Environmental and } \\
\text { resource productivity }\end{array}$} & \multicolumn{2}{|c|}{ Natural asset base } & \multicolumn{2}{|c|}{$\begin{array}{c}\text { Environmental } \\
\text { dimension of quality } \\
\text { of life }\end{array}$} & \multicolumn{2}{|c|}{$\begin{array}{c}\text { Economic } \\
\text { opportunities and } \\
\text { policy responses }\end{array}$} & \multicolumn{2}{|c|}{$\begin{array}{l}\text { Socio-economic } \\
\text { context }\end{array}$} \\
\hline Country & $\mathrm{h}_{\mathrm{i}}$ & Country & $\mathrm{h}_{\mathrm{i}}$ & Country & $\mathrm{h}_{\mathrm{i}}$ & Country & $\mathrm{h}_{\mathrm{i}}$ & Country & $\mathrm{h}_{\mathrm{i}}$ \\
\hline 1 & 2 & 3 & 4 & 5 & 6 & 7 & 8 & 9 & 10 \\
\hline \multicolumn{2}{|c|}{$\begin{array}{c}\text { Group I - high level } \\
\text { of development } \\
h_{i} \geq 0.569\end{array}$} & \multicolumn{2}{|c|}{$\begin{array}{c}\text { Group I - high level } \\
\text { of development } \\
h_{i} \geq 0.763\end{array}$} & \multicolumn{2}{|c|}{$\begin{array}{c}\text { Group I - high level } \\
\text { of development } \\
h_{i} \geq 0.782\end{array}$} & \multicolumn{2}{|c|}{$\begin{array}{c}\text { Group I - high level } \\
\text { of development } \\
h_{i} \geq 0.653\end{array}$} & \multicolumn{2}{|c|}{$\begin{array}{c}\text { Group I - high level } \\
\text { of development } \\
h_{i} \geq 0.745\end{array}$} \\
\hline Sweden & 0.676 & \begin{tabular}{|l|} 
Ireland \\
\end{tabular} & 1 & \begin{tabular}{|l|} 
Finland \\
\end{tabular} & 0.927 & Slovenia & 0.984 & \begin{tabular}{|l|} 
Ireland \\
\end{tabular} & 0.945 \\
\hline Denmark & 0.667 & \begin{tabular}{|l|} 
United \\
Kingdom
\end{tabular} & 0.960 & Sweden & 0.922 & \begin{tabular}{|l}
$\begin{array}{l}\text { Luxem- } \\
\text { bourg }\end{array}$ \\
\end{tabular} & 0.688 & Lithuania & 0.832 \\
\hline Latvia & 0.599 & Portugal & 0.917 & Ireland & 0.876 & - & - & Latvia & 0.817 \\
\hline- & - & Spain & 0.917 & Estonia & 0.875 & - & - & Sweden & 0.782 \\
\hline- & - & Finland & 0.818 & - & - & - & - & Estonia & 0.754 \\
\hline- & - & Greece & 0.800 & - & - & - & - & - & - \\
\hline \multicolumn{2}{|c|}{$\begin{array}{c}\text { Group II - medium } \\
\text { level of development } \\
0.397 \leq \mathrm{h}_{\mathrm{i}} \leq 0.569\end{array}$} & \multicolumn{2}{|c|}{$\begin{array}{l}\text { Group II - medium } \\
\text { level of development } \\
0.121 \leq \mathrm{h}_{\mathrm{i}} \leq 0.763\end{array}$} & \multicolumn{2}{|c|}{$\begin{array}{l}\text { Group II - medium } \\
\text { level of development } \\
0.359 \leq \mathrm{h}_{\mathrm{i}} \leq 0.782\end{array}$} & \multicolumn{2}{|c|}{$\begin{array}{c}\text { Group II - medium } \\
\text { level } \\
\text { of development } \\
0.294 \leq \mathrm{h} \leq 0.653\end{array}$} & \multicolumn{2}{|c|}{$\begin{array}{c}\text { Group II - medium } \\
\text { level of development } \\
0.373 \leq \mathrm{h}_{\mathrm{i}} \leq 0.745\end{array}$} \\
\hline Austria & 0.547 & Sweden & 0.748 & $\begin{array}{l}\text { United } \\
\text { Kingdom }\end{array}$ & 0.734 & Poland & 0.646 & \begin{tabular}{|l|} 
Slovak \\
Republic
\end{tabular} & 0.670 \\
\hline Italy & 0.527 & Italy & 0.672 & Lithuania & 0.706 & $\begin{array}{l}\text { Nether- } \\
\text { lands }\end{array}$ & 0.591 & France & 0.664 \\
\hline Ireland & 0.519 & France & 0.464 & Luxembourg & 0.675 & Estonia & 0.563 & $\begin{array}{l}\text { Czech } \\
\text { Republic }\end{array}$ & 0.642 \\
\hline Lithuania & 0.509 & Belgium & 0.401 & Denmark & 0.670 & \begin{tabular}{|l|} 
Slovak \\
Republic
\end{tabular} & 0.558 & Slovenia & 0.606 \\
\hline Netherlands & 0.508 & Netherlands & 0.355 & France & 0.642 & \begin{tabular}{|l|} 
Italy \\
\end{tabular} & 0.537 & Poland & 0.605 \\
\hline Portugal & 0.507 & \begin{tabular}{|l|} 
Denmark \\
\end{tabular} & 0.341 & Netherlands & 0.634 & Germany & 0.516 & \begin{tabular}{|l|} 
Denmark \\
\end{tabular} & 0.599 \\
\hline $\begin{array}{l}\text { United King- } \\
\text { dom }\end{array}$ & 0.505 & Luxembourg & 0.332 & Portugal & 0.631 & Latvia & 0.511 & Hungary & 0.554 \\
\hline Spain & 0.487 & \begin{tabular}{|l|} 
Estonia \\
\end{tabular} & 0.307 & \begin{tabular}{|l|} 
Germany \\
\end{tabular} & 0.554 & Austria & 0.495 & Finland & 0.524 \\
\hline Greece & 0.475 & Germany & 0.226 & Latvia & 0.546 & Germany & 0.469 & \begin{tabular}{|l|} 
United \\
Kingdom \\
\end{tabular} & 0.522 \\
\hline Luxembourg & 0.464 & Austria & 0.203 & Spain & 0.532 & $\begin{array}{l}\text { United } \\
\text { Kingdom }\end{array}$ & 0.469 & Austria & 0.506 \\
\hline Slovenia & 0.462 & \begin{tabular}{|l|} 
Slovenia \\
\end{tabular} & 0.196 & Austria & 0.532 & Greece & 0.459 & Luxembourg & 0.431 \\
\hline Belgium & 0.459 & Hungary & 0.175 & Belgium & 0.451 & France & 0.459 & Germany & 0.430 \\
\hline Finland & \begin{tabular}{|l|}
0.457 \\
\end{tabular} & \begin{tabular}{|l} 
Latvia \\
\end{tabular} & 0.145 & Slovenia & 0.426 & \begin{tabular}{|l|} 
Portugal \\
\end{tabular} & 0.451 & \begin{tabular}{|l} 
Belgium \\
\end{tabular} & 0.427 \\
\hline France & 0.443 & \begin{tabular}{|l} 
Slovak \\
Republic
\end{tabular} & 0.139 & $\begin{array}{l}\text { Slovak } \\
\text { Republic }\end{array}$ & 0.392 & $\begin{array}{l}\text { Czech } \\
\text { Republic }\end{array}$ & 0.428 & Spain & 0.410 \\
\hline $\begin{array}{l}\text { Slovak } \\
\text { Republic }\end{array}$ & 0.423 & - & - & - & - & Belgium & 0.418 & - & - \\
\hline Estonia & 0.423 & - & - & - & - & Hungary & 0.410 & - & - \\
\hline Hungary & 0.401 & - & - & - & - & Spain & 0.403 & - & - \\
\hline- & - & - & - & - & - & Finland & 0.370 & - & - \\
\hline \multicolumn{2}{|c|}{$\begin{array}{c}\text { Group III - low level } \\
\text { of development } \\
h_{\mathrm{i}}<0.397\end{array}$} & \multicolumn{2}{|c|}{$\begin{array}{c}\text { Group III - low level } \\
\text { of development } \\
h_{\mathrm{i}}<0.121\end{array}$} & \multicolumn{2}{|c|}{$\begin{array}{c}\text { Group III - low level } \\
\text { of development } \\
h_{\mathrm{i}}<0.359\end{array}$} & \multicolumn{2}{|c|}{$\begin{array}{c}\text { Group III - low } \\
\text { level } \\
\text { of development } \\
h_{\mathrm{i}}<0.294\end{array}$} & \multicolumn{2}{|c|}{$\begin{array}{c}\text { Group III - low level } \\
\text { of development } \\
h_{\mathrm{i}}<0.373\end{array}$} \\
\hline $\begin{array}{l}\text { Czech } \\
\text { Republic }\end{array}$ & \begin{tabular}{|l|}
0.390 \\
\end{tabular} & $\begin{array}{l}\text { Czech } \\
\text { Republic }\end{array}$ & 0.075 & Italy & 0.332 & Lithuania & 0.289 & Portugal & 0.319 \\
\hline Germany & 0.336 & Lithuania & 0.024 & $\begin{array}{l}\text { Czech } \\
\text { Republic }\end{array}$ & 0.320 & Ireland & 0.165 & Netherlands & 0.298 \\
\hline
\end{tabular}




\begin{tabular}{|c|c|c|c|c|c|c|c|c|c|}
\hline 1 & 2 & 3 & 4 & 5 & 6 & 7 & 8 & 9 & 10 \\
\hline Poland & 0.313 & Poland & 0.00 & Poland & 0.314 & Sweden & 0.012 & Greece & 0.290 \\
\hline- & - & - & - & Greece & 0.221 & - & - & Italy & 0.230 \\
\hline- & - & - & - & Hungary & 0.206 & - & - & - & - \\
\hline
\end{tabular}

Source: own elaboration.

Two linear methods (Hellwig and non-pattern) were used to assess green growth. In order to organize the results of both methods, Table 6 was prepared which presents the positions of countries according to the taxonomic measure of Hellwig's development and the non-pattern synthetic measure.

Table 6. Positions in the ranking of countries according to two scales of development level

\begin{tabular}{|l|c|c|c|}
\hline \multicolumn{1}{|c|}{ Country } & Ranking position $\mathrm{d}_{\mathrm{i}}$ & Change in ranking & Ranking position $\mathrm{h}_{\mathrm{i}}$ \\
\hline Austria & 9 & 5 & 14 \\
\hline Belgium & 19 & 2 & 17 \\
\hline Czech Republic & 20 & 0 & 5 \\
\hline Denmark & 2 & 3 & 3 \\
\hline Estonia & 10 & 7 & 4 \\
\hline Finland & 12 & 8 & 9 \\
\hline France & 5 & 4 & 18 \\
\hline Germany & 16 & 2 & 22 \\
\hline Greece & 22 & 0 & 23 \\
\hline Hungary & 23 & 0 & 2 \\
\hline Ireland & 3 & 1 & 19 \\
\hline Italy & 18 & 1 & 7 \\
\hline Latvia & 8 & 1 & 8 \\
\hline Lithuania & 7 & 1 & 10 \\
\hline Luxembourg & 6 & 4 & 13 \\
\hline Netherlands & 15 & 2 & 21 \\
\hline Poland & 21 & 0 & 11 \\
\hline Portugal & 14 & 3 & 16 \\
\hline Slovak Republic & 17 & 1 & 12 \\
\hline Slovenia & 13 & 1 & 15 \\
\hline Spain & 11 & 4 & 1 \\
\hline Sweden & 4 & 3 & 6 \\
\hline United Kingdom & 1 & 5 & \\
\hline
\end{tabular}

Source: own elaboration.

The results of assigning countries are relatively similar. The measures show similar results for low-developed countries but differ among high-developed countries. The obtained results may be different because the method of Hellwig's development pattern uses a synthetic development indicator. In turn, the non-pattern measure is based on the arithmetic mean of the normalized features. The graphical representation of the obtained result is presented on the radar chart below. 


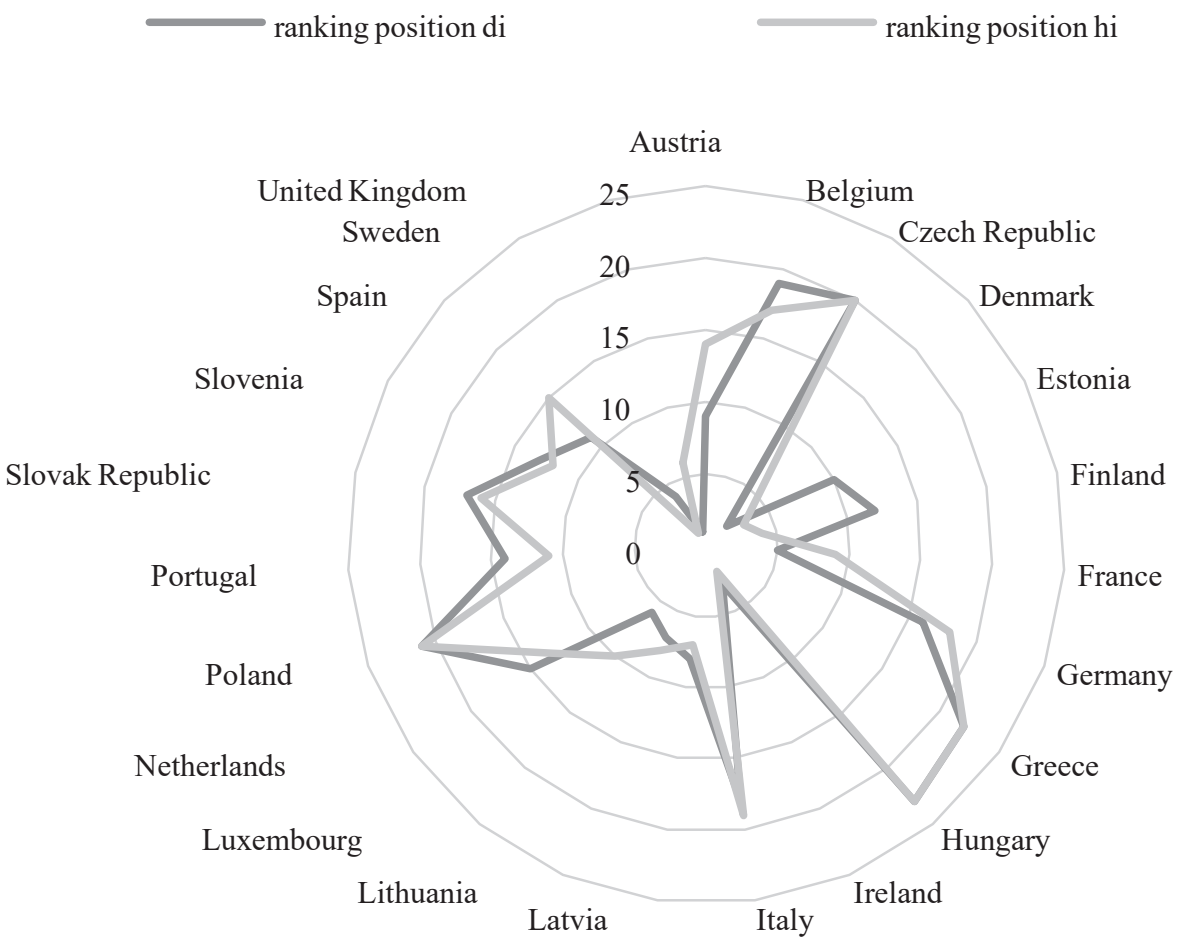

Fig. 2. Country positions by synthetic variables di and hi

Source: own elaboration.

\section{Assessment of green growth in the $E U$ countries with the use of cluster analysis}

Ward's method used in the study helped to complete the analysis, thus it was possible to notice the similarities of the examined objects without taking into account their hierarchy. The aggregation process is shown in Figure 3.

The graphic interpretation is the dendrogram shown in Figure 4.

Five relatively homogeneous spatial group were distinguished in the study:

A. Group 1: the Czech Republic, Hungary, Poland, the Slovak Republic, Slovenia

B. Group 2: Italy, Spain, Greece, Portugal

C. Group 3: Belgium, the Netherlands, France, the United Kingdom, Germany, Luxembourg

D. Group 4: Estonia, Finland, Austria, Denmark, Latvia, Lithuania, Sweden

E. Group 5: Ireland 


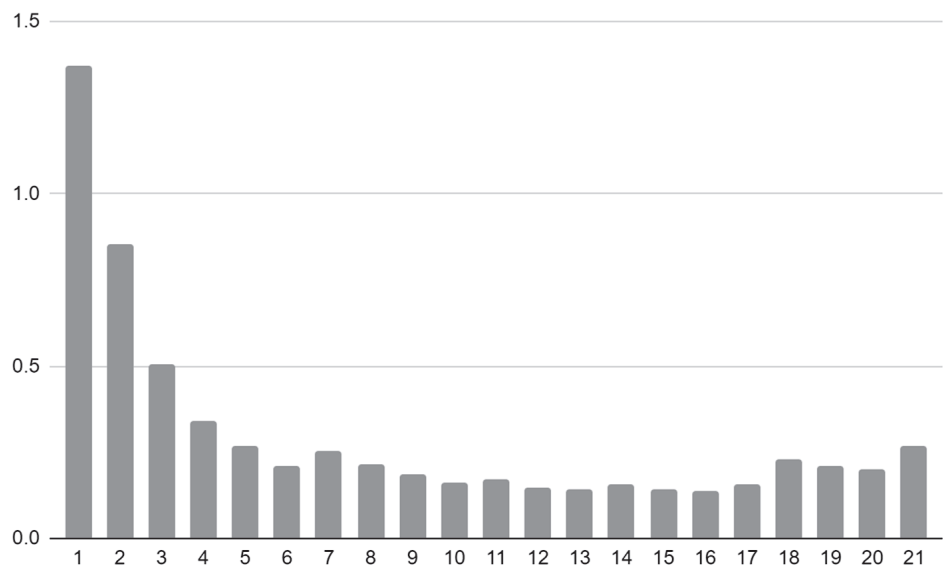

Fig. 3. Clustering rate

Source: own elaboration.

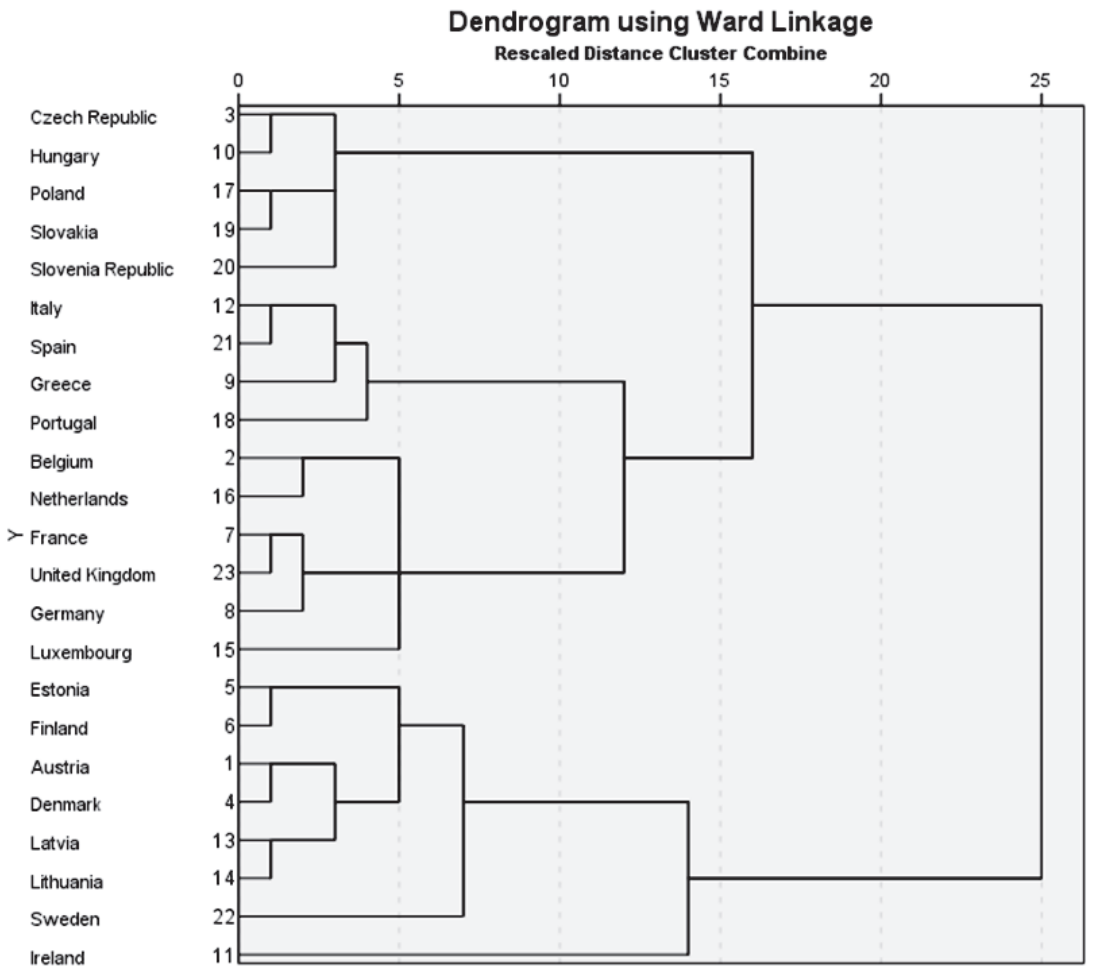

Fig. 4. The process of merging into clusters

Source: own elaboration. 


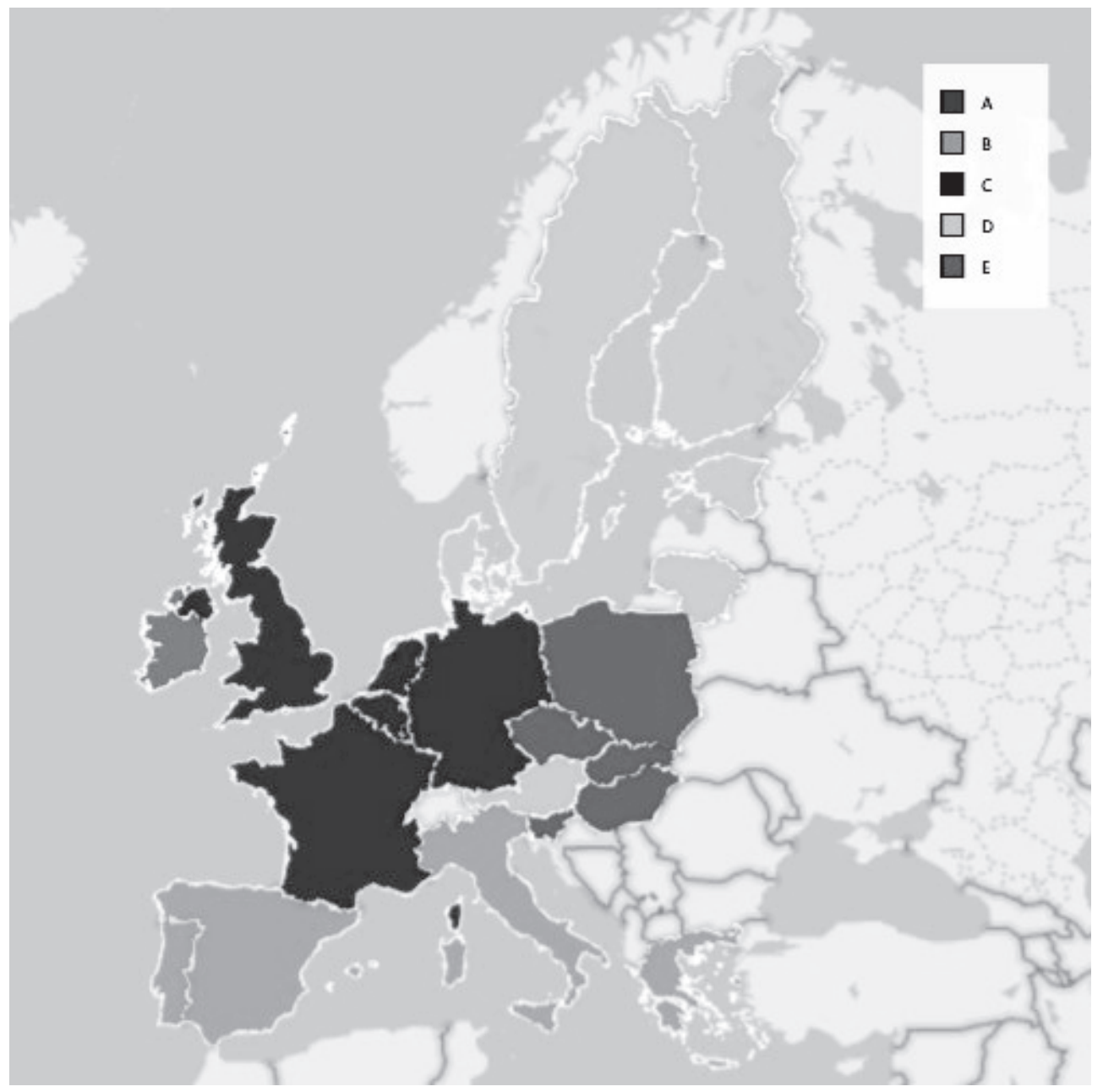

Fig. 5. Spatial differentiation of countries using Ward's method

Source: own elaboration.

Relatively similar countries were distinguished on the basis of Ward's method. They are diverse in relation to each other but some similarities can be found. Group A consists of countries with the lowest (Poland, Hungary, the Czech Republic) and average level of development (the Slovak Republic, Slovenia). Group B consists of countries with a low (Greece) and medium development level (Italy, Portugal, Spain). Group C consists of countries with the highest level of development (the United Kingdom) and medium (the Netherlands, Belgium, Germany). Group D includes countries located in the middle group, but close to the high level of development. Ireland is a country showing a high level of development. The similarity of the 
groups can also be seen in the non-pattern method. Group A consists of countries with a low level of development (the Czech Republic, Hungary, Poland) and medium development (the Slovak Republic and Slovenia). Group B is distinguished by slightly higher growth and, with the exception of Greece (low level of development), the countries are classified at the average level of development. Group $\mathrm{C}$ is distinguished by average measures (average level of development). Group D includes countries with a high level of development and the upper limit of middle development (excluding Austria). Ireland is at a high level of development. The countries show great similarities in terms of territoriality, as shown in Figure 5.

\section{Conclusion}

The green growth analysis which used linear (Hellwig's, non-pattern model) and non-linear (Ward's) methods, allowed for a comprehensive assessment of the phenomenon under study. A variety of approaches were taken to make it possible to compare countries, establish a hierarchy, and define the level of development in relation to other countries.

On the basis of the analysis performed, there is a large variation among the European Union countries regarding green growth. Although it is impossible to distinguish one leader who would dominate among all groups of indicators, there are countries that are classified in the area of high development. Based on Hellwig's method, it can be seen that the difference between the first (the United Kingdom, $\mathrm{d}_{\mathrm{i}}=0.346$ ) and the last country (Hungary: $\mathrm{d}_{\mathrm{i}}=0.015$ ) shows a large discrepancy. On the basis of the non-pattern method, a substantial difference can be noted (first place: $h_{i}=0.706$ and last place: $h_{i}=0.350$ ). Disproportion may prove to be a problem in the implementation of the sustainable development policy and in delivering on promises to improve the environment and citizens' quality of life in Europe.

It should be emphasized that most European Union countries are characterized by an average level of green development (16 countries in the II class according to the Hellwig method and 15 according to the non-pattern method). Based on Ward's method, five groups of countries that are relatively similar were distinguished. Ireland, which constitutes a separate group, deserves a special distinction. The countries show spatial similarity, which means that the level of green growth depends on location factors.

It can be seen that the level of green growth between the countries considered shows spatial similarity. The Czech Republic, Hungary, Poland, Slovenia and the Slovak Republic are the worst in terms of environmental factors, but have socioeconomic potential. It should be noted that Poland, Slovakia, Hungary and the Czech Republic are countries which make up the Visegrad Group. Therefore, their further analysis may be an interesting research field. Economically strong countries whose actions indicate respect for the natural environment, have similar indicators in each of the areas of green growth. Scandinavian countries that focus on high 
environmental care achieve high rates in the first three areas (environmental and resource productivity, natural asset base, environmental dimension of quality of life).

This study can be used in further research and can form the basis for further analyses of sustainable development and green growth in the examined EU countries. It is possible to apply the selected research methodology to the analysis of other groups of countries. The study also has practical implications, as it may become a valuable source of knowledge for authorities at all levels. The conducted research may be extended with data from previous years, which would allow to find out about the level of development of given countries and their involvement in the implementation of the green growth policy. The information contained in the article can be used for further analyses and constitute a starting point for defining an action strategy.

\section{References}

Abrahamse, W., Steg, L., Vlek, C., and Rothengatter, T. (2007). The effect of tailored information, goal setting, and tailored feedback on household energy use, energy-related behaviors, and behavioral antecedents. Journal of Environmental Psychology, 27, 265-276.

Acemoglu, D., Aghion, P., Bursztyn, L., and Hemous, D. (2011). The environment and directed technical change. American Economic Review, 102(1), 131-166.

Alrasheedi, M., Mardani, A., Mishra, A., Streimikiene, D., Liao, H., and Al-nefaie, A. (2020). Evaluating the green growth indicators to achieve sustainable development: A novel extended intervalvalued intuitionistic fuzzy-combined compromise solution approach. Sustainable Development, 29(1), 120-142. https://doi.org/10.1002/sd.2136

Basiura, B., and Sokołowski, A. (2005). Efektywność klasyfikacji w metodzie Warda. Folia Oeconomica Cracoviensia, 46, 53-64.

Ben-Eli, M. (2015). Sustainability: Definition and five core principles a new framework the sustainability laboratory. New York. Retrieved from info@sustainabilitylabs.org

Dauvergne, P. (2021). The globalization of artificial intelligence: Consequences for the politics of environmentalism. Globalizations, 18(1), 285-299.

European Union Treaty of Amsterdam. (1997). Retrieved from https://europa.eu/european-union/sites/ default/files/docs/body/treaty_of_amsterdam_en.pdf

Florczak, W. (2008). Wskaźniki zrównoważonego rozwoju. Wiadomości Statystyczne, 3, 14-34.

Hallegatte, S., Heal, G., Fay, M., and Treguer, D. (2012). From growth to green growth - a framework (NBER Working Paper Series), 2-39.

Hellwig, Z., Siedlecka, U., and Siedlecki, J. (1997). Taksonomiczne modele zmian struktury gospodarczej Polski. Warszawa: Instytut Rozwoju i Studiów Strategicznych.

Hickel, J., and Kallis, G. (2020). Is Green Growth possible? New Political Economy, 25(4), 469-486.

Jacobs, M. (2012). Green Growth: Economic theory and political discourse (Centre for Climate Change Economics and Policy. Working Paper, 108, Grantham Research Institute on Climate Change and the Environment. Working Paper, 92), 1-24.

Kasztelan, A. (2015). Zielony wzrost jako nowy kierunek rozwoju gospodarki w warunkach zagrożeń ekologicznych. Studia Ekonomiczne, 2, 185-186. 
Khoshnava, S. M., Rostami, R., Zin, R. M., Štreimikiene, D., Yousefpour, A., Mardani, A., and Alrasheedi, M. (2020). Contribution of green infrastructure to the implementation of green economy in the context of sustainable development. Sustainable Development, 28, 320-342.

Kim, S. E., Kim, H., and Chae, Y. (2014). A new approach to measuring green growth: Application to the OECD and Korea. Futures, 63, 37-48.

Kirchherr, J., Reike, D., and Hekkert, M. (2017). Conceptualizing the circular economy: An analysis of 114 definitions. Resources. Conservation and Recycling, 127, 221-232.

Komisja Europejska. (2016). European Commission - Basics of Green Economy. Retrieved March, 14, 2021 from http://ec.europa.eu/environment/basics/green-economy/resources/index_en.htm

Kubiczek, J., and Hadasik, B. (2021). Segmentation of passenger electric car market in Poland. World Electric Vehicle Journal, 12(1), 23. https://doi.org/10.3390/wevj12010023

Ministerstwo Środowiska. (1999). Strategia zrównoważonego rozwoju Polski do 2025. Wytyczne dla resortów. Warszawa.

Młodak, A. (2006). Analiza taksonomiczna w statystyce regionalnej. Warszawa: Difin.

OECD. (2010). Green Growth Indicators 2017. Retrieved March 20, 2021 from http://www.oecd-ilibrary.org

OECD. (2011). Toward Green Growth. Retrieved from https://www.oecd.org/greengrowth/48012345.pdf

OECD. (2017). Green Growth Indicators 2017. OECD Green Growth Studies.

Pawłowski, A. (2006). The multidimensional nature of sustainable development. Problemy Ekorozwoju: studia filozoficzno-sozologiczne, 1(1), 23-32.

Perło, D., and Roszkowska, E. (2011). Zastosowanie wybranych metod klasyfikacji do analizy zrównoważonego rozwoju. Wzrost Gospodarczy. Teoria. Rzeczywistość. Zeszyty Naukowe Uniwersytetu Ekonomicznego w Poznaniu, 176.

Rokicka, E., and Woźniak, W. (2016). W kierunku zrównoważonego rozwoju. Koncepcje, interpretacje, konteksty. Łódź: Uniwersytet Łódzki.

Ryszkowska, B. (2013). The concept of the green economy as an answer to the economic and environmental crisis. In A. Graczyk (Ed.), Polityka zrównoważonego i zasobooszczędnego gospodarowania (pp. 47-56). Wrocław: Wydawnictwo Uniwersytetu Ekonomicznego we Wrocławiu.

Silvestrea, B., and Țîrcă, D. (2019). Innovations for sustainable development: Moving toward a sustainable future. Journal of Cleaner Production, 208, 325-332.

Stoddart, H., Schneeberger, K., Dodds, F., Shaw, A., Bottero, M., Cornforth, J., and White, R. (2011). A pocket guide to sustainable development governance. Stakeholder Forum.

Stoknes, P., and Rockstrom, J. (2018). Redefining green growth within planetary boundaries. Energy Research \& Social Science, 44, 41-49.

Strahl, D. (2006). Metody oceny rozwoju regionalnego. Wrocław: Wydawnictwo Akademii Ekonomicznej we Wrocławiu.

Sulich, A., Grudziński, A., and Kulhanek, L. (2020). Green economic growth - comparative analysis for Czechia and Poland. Prace Naukowe Uniwersytetu Ekonomicznego we Wrocławiu, 64(5), 192$-207$.

Thomas, C. F. (2015). Naturalizing sustainability discourse: Paradigm, practices and pedagogy of Thoreau, Leopold. Carson and Wilson: PhD Thesis: Arizona State University.

Ukaga, U., Maser C., and Reichenbach, M. (2011). Sustainable development: Principles, frameworks, and case studies. International Journal of Sustainability in Higher Education, 12(2). doi:10.1108/ ijshe.2011.24912bae.005

UNEP. (2011). Towards a Green Economy: Pathways to sustainable development and poverty eradication. Retrieved from https://sustainabledevelopment.un.org/index.php?page $=$ view\&type $=400 \&$ $\mathrm{nr}=126 \& \mathrm{menu}=35$

United Nations General Assembly. (1987). Report of the World Commission on Environment and Development: Our Common Future. Oslo: United Nations General Assembly, Development and International Co-operation: Environment. 
Walesiak, M. (2009). Analiza skupień. In M. Walesiak, E. Gatnar (Eds.), Statystyczna analiza danych $z$ wykorzystaniem programu R (pp. 407-433). Warszawa: Wydawnictwo Naukowe PWN.

Wang, Y., Sun, X., and Guo, X. (2019). Environmental regulation and green productivity growth: Empirical evidence on the Porter Hypothesis from OECD industrial sectors. Energy Policy, 132, 611$-619$.

Ward, J. H. (1963). Hierarchical grouping to optimize an objective function. Journal of the American Statistical Association, 58, 236-244.

World Bank. (2012). Inclusive Green Growth. The Pathway to Sustainable Development. Retrieved from https://sustainabledevelopment.un.org/index.php?page=view\&type $=400 \& n r=690 \& m e n u=1515$

Wyszkowka, D., and Rogalska, A. (2014). Monitorowanie zielonej gospodarki w ujęciu organizacji międzynarodowych. Optimum. Studia Ekonomiczne, 3(69), 33-51.

Zarębska, J. (2017). Gospodarka o obiegu zamkniętym drogą do zrównoważonego rozwoju. Systemy Wspomagania w Inżynierii Produkcji, 6(7), 286-295.

\section{WIELOWYMIAROWA ANALIZA ZIELONEGO WZROSTU KRAJÓW UNII EUROPEJSKIEJ W 2019 ROKU}

Streszczenie: Zielony wzrost jest nowym podejściem do gospodarki, które zakłada efektywne wykorzystywanie surowców przy minimalizowaniu negatywnego wpływu na środowisko. Celem pracy jest ocena zielonego wzrostu w krajach Unii Europejskiej w roku 2019. W tym celu wykorzystano dane wtórne oraz posłużono się wielowymiarową analizą zrównoważonego rozwoju. Wykorzystano metodę bezwzorcową, Hellwiga oraz Warda. Umożliwiło to porównanie między krajami oraz ich klasyfikację ze względu na podobny poziom rozwoju. Na podstawie analizy stwierdzono dużą rozbieżność w zakresie zielonego wzrostu w analizowanych krajach. Zauważono, że dysproporcja może się okazać problemem w realizacji polityki zrównoważonego rozwoju. Wyniki badań pokazały, że pozycja kraju ma odzwierciedlenie w położeniu geograficznym.

Słowa kluczowe: analiza wielowymiarowa, analiza taksonomiczna, metoda Hellwiga, zielony wzrost, zrównoważony rozwój. 